\title{
Hvordan kan miljø- og klimahensyn integreres i den økonomiske politik?
}

Rasmus Kehlet Berg, ph.d.-studerende, Økonomisk Institut, Københavns Universitet; Janek Bligaard Eskildsen*, ph.d.-studerende, Økonomisk Institut, Københavns Universitet; Jens Villiam Hoff, professor, Institut for Statskundskab, Københavns Universitet; Jette Bredahl Jacobsen, professor, Institut for Fødevare- og Ressourceøkonomi og Center for Makroøkologi, Evolution og Klima, Københavns Universitet; Ole Gravgaard Pedersen, chefkonsulent, Danmarks Statistik; Martin Møller Boje Rasmussen, postdoc, Institut for Statskundskab, Københavns Universitet; Peter Philip Stephensen, forskningschef, DREAM-modelgruppen og Peter Birch Sørensen, professor, Økonomisk Institut, Københavns Universitet

I 2016-17 bevilgede KR-fonden og Carlsbergfondet midler til finansiering af det tvarvidenskabelige, fireårige forskningsprojekt 'Developing and Implementing Green National Accounts and the Green GDP'. Projektet gennemføres $i$ et samarbejde mellem forskere fra Økonomisk Institut, KU, Institut for Statskundskab, KU, Institut for Fødevare- og Ressourceøkonomi, KU samt ansatte i Danmarks Statistik og DREAM-modelgruppen. Projektet har som overordnet formål at belyse og bestyrke forudsatningerne for en mere systematisk integration af klima- og miljøhensyn i den mellemfristede økonomiske planlaegning $i$ Danmark. Som led heri undersøger projektet blandt andet hvorvidt, i hvilket omfang og hvordan Danmarks nuvorende grønne nationalregnskab indgår og anvendes i relevante politisk-økonomiske beslutningsprocesser, ligesom der i regi af projektet udvikles en ny miljø- og klimaøkonomisk model for dansk økonomi samt en beregning af Danmarks grønne BNP. Norvorende artikel beskriver de redskaber, der kan anvendes til systematisk at samtonke økonomi og miljø, samt dele af de indledende resultater fra forskningsprojektet.

1. Indledning: Behovet for samtænkning af økonomi og miljø

Naturvidenskaberne har igennem årtier til overflod dokumenteret, hvordan vores naturgivne miljø er under stigende pres fra udviklingen i de menneskelige samfund. I forskerverdenen er begrebet "den antropocene periode" efterhånden alment accepteret som betegnelse for den nuværende epoke i klodens historie, hvor menneskelige aktiviteter for første gang er blevet den dominerende drivkraft for ændringerne i de globale økosystemer (Crutzen 2002; Ruddiman 2013; Steffen m.fl. 2018). 
Selvom der ikke er en entydig sammenhæng mellem udviklingen i det enkelte lands bruttonationalprodukt (BNP) og belastningen af miljøet, er det ubestrideligt, at de seneste årtiers vækst i den globale økonomi har været ledsaget af et stærkt stigende globalt forbrug af materialer såsom metaller, ikke-metalliske mineraler (sten, ler, grus, sand mm.), fossile brændsler og biomasse (Schandl m.fl. 2017). Det følger af termodynamikkens love, at bearbejdningen og omdannelsen af disse materialer i produktions- og forbrugsprocesserne skaber stigende mængder af rest- og affaldsprodukter, som i et eller andet omfang belaster miljøet. Termodynamikkens anden lov (den såkaldte entropilov) implicerer fx populært sagt, at en 100 pct. genanvendelse af materialer er fysisk umulig. En økonomisk udvikling, der baserer sig på et fortsat stigende fysisk materialeforbrug, er således ikke miljømæssigt holdbar i det lange løb.

I Danmark er det samlede materialeforbrug kun steget svagt siden starten af 1990'erne, og det er bl.a. lykkedes at reducere de danske drivhusgasindledninger og udledningen af en række andre forurenende stoffer betydeligt, jf. Sørensen (2019a). Ligesom det er tilfældet for mange andre gamle OECD-lande, skyldes forbedringen i en række indikatorer for miljøbelastningen dog delvis, at store dele af de mest miljøbelastende former for industriproduktion er udflyttet til de nye vækstøkonomier. Fx har Danmarks stigende import fra Kina været ledsaget af en stigende $\mathrm{CO}_{2}$-udledning afledt af danskernes forbrug samtidigt med de faldende udledninger fra dansk grund, jf. Levitt m.fl. (2015). Endvidere har Klimarådet (2018) påpeget, at udviklingen i drivhusgasudledningen fra Danmark langt fra er på sporet mod en opfyldelse af det politiske mål om nettonuludledning i 2050. Dertil kommer, at Danmark har problemer med at leve op til kravene til vandmiljøkvaliteten i EU's Vandrammedirektiv og til målsætningerne om beskyttelse af biodiversiteten i den international Aichi konvention, jf. Sørensen (2019a).

Da den økonomiske udvikling altså fortsat sætter miljøet under pres, og da efterlevelsen af Paris-aftalen om klimapolitikken vil kræve grundlæggende omstillinger i vores energisystem og landbrugsproduktion, er der behov for, at målene for miljø-, energiog klimapolitikken integreres langt mere systematisk i planlægningen af den økonomiske udvikling og den økonomiske politik. Til det formål har politikere, embedsmænd og andre beslutningstagere brug for nye analyseværktøjer, der kan belyse, hvordan den økonomiske aktivitet i samfundets forskellige sektorer påvirker miljøet, og hvilke politiske tiltag, der kan sikre en økonomisk udvikling, som lever op til de miljø- og klimapolitiske mål.

På den baggrund har et hold af forskere fra institutterne for Statskundskab, Økonomi, og Fødevare- og Ressourceøkonomi på Københavns Universitet i samarbejde med Danmarks Statistik og DREAM-modelgruppen påbegyndt to nært beslægtede forskningsprojekter om sammenhængene mellem økonomi og miljø i Danmark. Det ene projekt har til formål at udvikle en metode til beregning af Danmarks "Grønne BNP" og at belyse, hvordan vores grønne nationalprodukt har udviklet sig i de seneste årtier. Det andet projekt om den "GRØNNE REFORM model” har til formål at udvikle en miljø- og klimaøkonomisk simulationsmodel for dansk økonomi, der kan bruges til at vurdere miljø- og 
klimaeffekterne af den planlagte økonomiske udvikling samt de samfundsøkonomiske og erhvervsøkonomiske effekter af miljø-, energi- og klimapolitikken.

Projekterne støttes af bevillinger fra KR-Fonden og Carlsbergfondet, og projektet om den GRØNNE REFORM model har for nylig modtaget støtte fra Finansministeriet, der forventer at kunne bruge modellen. Mens projektet om det Grønne BNP kan belyse, om den historiske og aktuelle økonomiske vækst er sket på bekostning af miljøet, kan den GRØNNE REFORM model bruges til at vurdere, hvordan den fremadrettede økonomiske udvikling kan forventes at påvirke miljø og klima, og hvordan udviklingen kan bringes $\mathrm{i}$ overensstemmelse med de politiske mål på disse områder. Begge projekter trækker på data fra Danmarks Statistiks grønne nationalregnskab suppleret med andre datakilder. Økonomerne på forskerholdet indsamler data, udvikler beregningsmetoder for det Grønne BNP og opstiller og programmerer den nye miljø- og klimaøkonomiske model for dansk økonomi, mens politologerne på forskerholdet udforsker de politiske og institutionelle barrierer, der måtte være for at tage sådanne nye analyseværktøjer i brug i de danske politiske og administrative processer.

I det følgende redegør vi nærmere for de to projekter og præsenterer nogle af vore foreløbige forskningsresultater.

\section{Det grønne BNP}

\subsection{Kontroversen om BNP}

Det konventionelle bruttonationalprodukt måler værdien af den samlede produktion af varer og tjenester, der omsættes på private markeder, plus omkostningen ved produktion af den offentlige service, fratrukket værdien af de anvendte råstoffer. BNP er altså et mål for størrelsen af den samlede værditilvækst i landet, og den økonomiske vækst måles derfor ved stigningen i BNP (renset for inflation).

Økonomisk vækst har traditionelt været et af de vigtigste mål for de fleste politiske partier, fordi væksten øger den samlede realindkomst, der er til rådighed til fordeling i samfundet. Samtidigt har det traditionelle BNP i årtier været prügelknabe for de mange kritikere, som mener, at der bør være andre og højere mål for samfundsudviklingen end stadigt stigende materiel velstand. De økonomer, der stod faddere til udviklingen af det traditionelle nationalregnskab, har dog aldrig opfattet BNP som et mål for samfundets velfærd. Nobelpristageren Simon Kuznets, der i 1930'erne var en af ophavsmændene til BNP-begrebet, advarede tværtimod eksplicit mod en sådan tolkning af BNP, idet han bl.a. også betonede vigtigheden af, hvordan produktionen sammensættes, og produktionsresultatet fordeles. Det traditionelle BNP skal ikke opfattes som andet og mere end et pragmatisk forsøg på at måle den samlede økonomiske aktivitet i samfundet.

I de senere år har en lang række indflydelsesrige politikere og opinionsdannere verden over krævet et “opgør” med BNP og efterlyst alternative mål for samfundsvelfær- 
den, og EU-Kommissionen har taget det såkaldte "Beyond GDP initiative", hvis målsætning er formuleret således: "The Beyond GDP initiative is about developing indicators that are as clear and appealing as GDP, but more inclusive of environmental and social aspects of progress."1

Et stort antal forskere og tænketanke har allerede søgt at imødekomme efterspørgslen efter et alternativ til BNP ved at foreslå forskellige indeks for samfundsmæssige fremskridt, der sammenvejer en række indikatorer for samfundets tilstand. De mange forskellige bud på alternativer til BNP illustrerer det utopiske $i$ at forsøge at måle samfundsvelfærden med et enkelt tal.

Det Grønne BNP skal derfor ikke opfattes som et mål for samfundsvelfærden, men som et forsøg på at belyse, om den økonomiske vækst sker på bekostning af miljøet, eller om det traditionelle BNP tværtimod i perioder undervurderer væksten, hvis man tager hensyn til de miljøforbedringer, der måtte være sket. Dermed forsøger det grønne BNP at leve op til EU-kommissionens krav om en indikator, der er "as clear and appealing as GDP". Faktisk tillader vi os at mene, at det grønne BNP er "more appealing than GDP", da det på en systematisk måde inddrager miljøets betydning for økonomien. ${ }^{2}$

\subsection{Hvad er det grønne BNP?}

Det miljøøkonomiske teorigrundlag for det grønne BNP er nærmere beskrevet i Sørensen (2019b), der bl.a. bygger videre på pionérbidragene fra Hartwick (1990, 1994), Mäler (1991), Hamilton (1994), og Dasgupta og Mäler (2000). Tidligere er teorien bl.a. blevet anvendt til at beregne udviklingen i det grønne BNP i Skotland (Pezzey m.fl. 2006) og i Portugal (Mota m.fl. 2010). Det grønne BNP, der i den miljøøkonomiske litteratur mere præcist betegnes som det Grønne Nettonationalprodukt (GNNP), beregnes i to trin. Først opgøres nettonationalindkomsten (NNI) på følgende måde:

$$
\mathrm{NNI}=\mathrm{BNP}-\text { afskrivninger på fysisk realkapital + nettoindkomst fra udlandet }
$$

Nettonationalindkomsten tager altså højde for, at en del af produktionsresultatet (BNP) skal sættes til side for at kompensere for nedslidning af de eksisterende maskiner, bygninger, veje mv. Til gengæld skal nettoindtægterne fra danskejede formuer i udlandet lægges til for at nå frem til den samlede nettoindkomst, der tilfalder danskerne. Tallet for NNI findes allerede i det nuværende nationalregnskab, hvor man også beregner BNP.

Det næste trin i beregningen af det Grønne Nettonationalprodukt går imidlertid videre end det traditionelle nationalregnskab ved at korrigere NNI for miljøeffekter:

\footnotetext{
${ }^{1}$ Se http://ec.europa.eu/environment/beyond_gdp/index_en.html.

${ }^{2}$ Hvis man (restriktivt og urealistisk) antager, at borgernes velfærd alene afhænger af deres forbrug af traditionelle goder og forbruget af kulturelle økosystemtjenester, kan man vise, at "samfundsvelfærden" er proportional med det Grønne Nettonationalprodukt, jf. Sørensen (2019b).
} 
GNNP = NNI + værdi af forbrug af miljøtjenester + værdi af nettotilvækst i naturkapital

GNNP kan altså opfattes som et miljøkorrigeret BNP, der sætter fokus på miljøets betydning for økonomien. Da nettonationalindkomsten (NNI) i det traditionelle nationalregnskab anvendes til offentligt eller privat forbrug af traditionelle varer og tjenester eller til investering $\mathrm{i}$ indenlandsk realkapital (maskiner, bygninger, infrastruktur mm.) eller til erhvervelse af fordringer på udlandet (fx udenlandske værdipapirer), kan GNNP også opgøres på denne alternative måde:

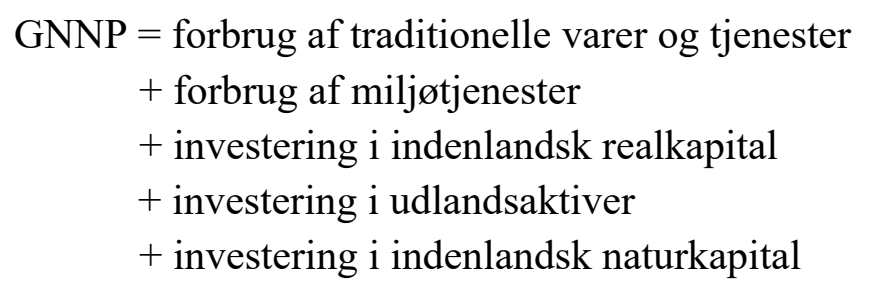

Vi ser, at GNNP opererer med et udvidet mål for det samlede forbrug, der inkluderer værdien af borgernes forbrug af miljøtjenester. Miljøtjenesterne inkluderer goder såsom ren luft, rent vand, og rekreative tjenester i bred forstand, herunder naturens herlighedsværdier og værdien af et rigt dyre- og planteliv. Fælles for de miljøtjenester, der regnes som forbrugsgoder, er, at de alle bidrager direkte til borgernes velfærd, selvom de i modsætning til traditionelle goder ikke omsættes på markeder.

Vi ser også af opstillingen ovenfor, at GNNP arbejder med et udvidet mål for de samlede investeringer, der inkluderer investeringer i "naturkapital" (svarende til den post, vi ovenfor har kaldt "værdi af nettotilvækst i naturkapital"). Hermed menes fx værdien af en tilvækst i skovenes biomasse eller i fiskebestande. Selvom dette betegnes som en investering, er det værd at bemærke, at tilvæksten i fornybare ressourcer grundlæggende kommer af sig selv, men at den kan påvirkes af mennesker og endog blive negativ som følge af fx skovrydning og overfiskeri. Tilvækst i beholdningen af udtømmelige ressourcer via fx nye fund af olie og gas opfattes også som en investering i naturkapital ligesom eventuelle forbedringer af kvaliteten af luft og vand. Omvendt regnes forbrug af eksisterende udtømmelige naturressourcer samt en eventuel forringelse af luftkvaliteten og vandkvaliteten og en nedbringelse af havenes og skovenes biomasse som en negativ investering i naturkapital. Udledning af drivhusgasser indgår ligeledes negativt, fordi den reducerer det tilbageværende " $\mathrm{CO}_{2}$-budget" for de fremtidige udledninger, som Danmark kan tillade sig, hvis vi skal leve op til vore internationale klimapolitiske forpligtelser.

Summen af investeringer i indenlandsk menneskeskabt kapital, udlandsaktiver og naturkapital kaldes i den miljøøkonomiske litteratur for samfundets "ægte opsparing”. Vismandsinstitutionen har med mellemrum opgjort udviklingen i Danmarks ægte opsparing, jf. fx De Økonomiske Råd (2017). Det grønne BNP går et skridt videre, da det både inkluderer den ægte opsparing og værdien af det løbende forbrug af ikke-markedsomsatte miljøgoder. Værdien af disse tjenester afhænger afgørende af geografiske aspekter. Fx afhænger den samlede rekreative værdi og herlighedsværdien af et naturområde i høj grad 
af, hvor mange mennesker der bor i nærheden af området og dermed hurtigt og billigt kan få adgang til det. Dette er aspekter, man i de seneste år har viet stor opmærksomhed i kortlægningen og værdisætningen af såkaldte økosystemtjenester (fx TEEB 2010 og Bateman et al. 2013). Man skelner mellem forsynende, regulerende og kulturelle økosystemtjenester. De forsynende tjenester er i vidt omfang markedsførte, fx tømmer, fisk, mv. og dermed indregnet $i$ det almindelige BNP. De regulerende økosystemtjenester - $\mathrm{fx}$ bestøvning - medregner man ikke, da deres værdi afspejles i værdien af landbrugsprodukter.

Endelig er de kulturelle økosystemtjenester, de ikke-materielle tjenester, som mennesker får fra naturen i form af fx friluftsliv, herligheds- og eksistensværdier, bidrag til kognitiv udvikling og spirituel berigelse mm. Disse tjenester er notorisk vanskelige at værdisætte på et nationalt plan, og er derfor ikke indregnet andre steder. Vi bidrager til litteraturen om værdisætning og grønt BNP ved at udvikle en metode, der gør det muligt at beregne den samlede værdi på landsplan ud fra studier af deres lokale værdi i specifikke områder. Dette gøres med udgangspunkt i et detaljeret kort over Danmark, der identificerer den geografiske fordeling af en række økosystemtjenester. På den måde kan man belyse, hvordan arealanvendelsen og ændringer heri (såsom oprettelsen af en nationalpark) påvirker det grønne BNP.

\subsection{Værdisætning af miljøgoder: Giver det mening?}

Den store udfordring ved beregningen af GNNP er at værdisætte ikke-markedsomsatte miljøgoder såsom vandkvalitet, luftkvalitet, rekreative naturværdier, biodiversitet mm. I den miljøpolitiske debat møder man ofte synspunktet, at det ikke giver mening at opgøre værdien af miljøgoder i kroner og øre, da der er tale om goder, som er kvalitativt forskellige fra materielle goder, der omsættes i markedet. Dette synspunkt bunder ofte i en idealistisk opfattelse af, at naturen og miljøet er (eller burde være) ukrænkelige værdier, som vi mennesker ikke har ret til at forringe. Sagen er imidlertid, at stort set al menneskelig aktivitet i større eller mindre omfang påvirker miljøet, og at vi både individuelt og kollektivt hver eneste dag træffer valg, som indebærer en implicit prioritering mellem miljøgoder og andre goder. Når vi fx vælger at køre i (en fossilt drevet) bil frem for at gå eller cykle, viser vi dermed, at det har større værdi for os at komme hurtigt frem end at undgå den luft- og støjforurening, som vores bilkørsel medfører. Og når vore valgte politikere beslutter at anlægge veje og broer, der beslaglægger naturarealer og medfører færre levesteder for dyr og planter, har de implicit prioriteret bedre transportmuligheder højere end bevarelsen af de habitatfunktioner og herlighedsværdier, som de beslaglagte naturarealer leverede.

Miljøøkonomernes værdisætning af miljøgoder tager udgangspunkt i den erkendelse, at både traditionelle varer og tjenester og miljøgoder bidrager til menneskelig velfærd, og at man ikke kommer uden om at skulle prioritere imellem dem i et eller andet 
omfang. En eksplicit værdisætning af miljøgoder kan skabe en større bevidsthed om miljøets betydning for velfærden og økonomien og sikre, at den uomgængelige prioritering (hvor meget er vi villige til at betale for et bedre miljø?) sker på en konsistent og transparent måde på tværs af tid og sted.

Miljøøkonomerne har i tidens løb udviklet en række alternative værdisætningsmetoder, jf. Dubgaard og Ladenburg (2007). En grundlæggende sondring går mellem omkostningsbaserede og præferencebaserede metoder. De omkostningsbaserede metoder søger at estimere omkostningen ved at opnå en (politisk) ønsket miljøtilstand. Værdien af en ændring i mængden af det betragtede miljøgode sættes lig med omkostningen ved at opnå en ønsket forbedring (eller ved at undgå en uønsket forringelse) af miljøtilstanden, fx luftkvaliteten eller vandkvaliteten. De præferencebaserede metoder søger derimod at afdække, hvor meget borgerne samlet set er villige til at betale for at opnå en given miljøforbedring eller undgå en given miljøforringelse.

Som vist i Sørensen (2019b) tilsiger velfærdsteoretiske overvejelser, at man som hovedregel bør værdisætte miljøgoder med udgangspunkt i borgernes betalingsvillighed, dvs. ved brug af præferencebaserede metoder. Der kan dog tænkes situationer, hvor opfyldelsen af Danmarks forpligtelser i henhold til internationale miljø- eller klimaaftaler indebærer en samfundsøkonomisk marginalomkostning, der overstiger borgernes estimerede marginale betalingsvillighed. I sådanne situationer vil vi benytte en omkostningsbaseret værdisætningsmetode ved opgørelsen af GNNP ud fra den betragtning, at Danmark skal overholde sine internationale forpligtelser.

\section{4. "Stærk" contra "svag" bæredygtighed}

I definitionen af GNNP i sektion 2.2 sammenlægges de konventionelle økonomiske værdier fra det traditionelle BNP/NNI med værdien af forbrug af miljøgoder samt investeringen i naturkapital. Det antages således implicit, at eventuelle skader på miljøet kan opvejes af en passende stigning i forbruget af konventionelle goder eller større investeringer i menneskeskabt kapital. Udviklingen betragtes således som bæredygtig, så længe GNNP ikke falder. Dette bæredygtighedsbegreb kaldes i litteraturen for "svag bæredygtighed", jf. Neumayer (2013). Heroverfor står de økologiske økonomers krav om "stærk bæredygtighed", som indebærer, at der ikke må ske forringelser af den samlede naturkapital, jf. fx Daly og Farley (2011). Implicit bag dette krav ligger en opfattelse af, at menneskeskabt kapital ikke kan erstatte naturkapital, men at naturkapitalen tværtimod er en forudsætning for opbygning og brug af menneskeskabt kapital.

Det er klart, at der findes nogle basale livsunderstøttende økosystemtjenester ( $\mathrm{fx}$ luft og vand af tilstrækkelig kvalitet, dyrkbar jord, osv.), som er forudsætningen for menneskeligt liv. Dermed er der også nogle kritiske nedre grænser for, hvor meget naturkapitalen kan nedbringes og erstattes af menneskeskabt kapital. Så længe man befinder sig i "passende" sikkerhedsafstand af disse grænser, vil der dog som argumenteret af Stern (1997) være mulighed for en vis substitution mellem miljøgoder og konventionelle goder. 
I en sådan situation kan det give god mening at måle bæredygtighed ved udviklingen i GNNP. Samtidigt har udviklingen i naturkapitalen betydelig selvstændig interesse. Da investeringen i naturkapital indgår som en særskilt komponent i GNNP, vil opgørelsen af GNNP også gøre det muligt at vurdere, om udviklingen er "stærkt" bæredygtig.

\section{En dansk miljøøkonomisk simulationsmodel: GRØN REFORM}

Projektet om det Grønne BNP vil gøre det muligt at vurdere, om den historiske og aktuelle økonomiske vækst er sket på bekostning af miljøet. I projektet om den GRØNNE REFORM model udvikler vi en miljø- og klimaøkonomisk model for dansk økonomi, der kan bruges til at vurdere, hvordan den fremadrettede økonomiske udvikling kan forventes at påvirke miljø og klima, og hvordan udviklingen kan bringes i overensstemmelse med de politiske mål på disse områder.

Modellen skal indeholde en detaljeret beskrivelse af økonomiens forskellige sektorer med vægt på beskrivelsen af de brancher, der har særlig betydning for udviklingen i miljøtilstanden og udledningen af drivhusgasser såsom energisektoren, transportsektoren, landbruget og affalds- og genanvendelsessektoren. Modellen tager udgangspunkt $\mathrm{i}$ den samme modelkerne, der indgår i den nye makroøkonomiske model for dansk økonomi, som DREAM-gruppen er ved at udvikle for Finansministeriet. Derved sikres konsistens mellem beregningsforudsætningerne for fremskrivningerne af dansk økonomi og af de heraf afledte miljø- og klimamæssige konsekvenser.

I skrivende stund er arbejdet med modellering af energi- og transportsektoren det mest fremskredne. Nedenfor lægger vi derfor særlig vægt på beskrivelsen af disse sektorer, men forinden giver vi en generel introduktion til problemstillinger vedrørende anvendelsen af økonomiske modeller som GRØN REFORM.

\subsection{GRØN REFORM som analyseværktøj}

Som alle andre fremskrivningsmodeller ligger GRØN REFORM under for den basale kritik, at det er umuligt at spå om fremtiden. Selvom simulationsmodeller aldrig kan forudsige fremtiden præcist, muliggør de en analyse af fænomener, der endnu ikke er indtruffet og kan fortælle os, hvilke problemstillinger vi bør være opmærksomme på ud fra den viden, vi har i dag. GRØN REFORM har til formål at identificere problemer og områder, som er kritiske for den grønne omstilling i Danmark. Dette sker med udgangspunkt i en detaljeret modellering af de mest forurenende sektorer. I en klimasammenhæng er landbruget, industrien, transporten og energiforsyningen de centrale brancher, da de 
ifølge Danmarks Statistik stod for ca. $87 \%$ af de samlede drivhusgasudledninger fra virksomhederne i $2017 .^{3}$

Fra et miljøøkonomisk synspunkt tegner der sig et tilsvarende billede af disse branchers betydning for den grønne omstilling. For alle forurenende stoffer opgjort i Danmark Statistiks grønne nationalregnskab står disse fire sektorer for mindst $89 \%$ af de samlede udledninger fra virksomhederne i 2016. Særligt transportsektoren står for en relativt høj andel af udledningerne; kun overgået af landbruget, når det kommer til ammoniak (NH3) og ikke-metanholdige flygtige organiske forbindelser (NMVOC). Modellen vil endvidere indeholde en detaljeret beskrivelse af affaldshåndteringssektoren, for at kunne vurdere betydningen af genanvendelse (cirkulær økonomi) for den grønne omstilling.

\section{2. Økonomiske, miljøøkonomiske og tekniske modeller: Byggestenene for GRØN REFORM}

I gængse anvendte generelle ligevægtsmodeller såsom REFORM er de ovennævnte kritiske sektorer modelleret på lige fod med andre sektorer. Sektorerne bygger på den samme generelle struktur, hvilket øger modellens gennemsigtighed.

Den begrænsede detaljeringsgrad implicerer imidlertid, at der ikke sondres mellem forskellige teknologier, der anvendes i produktionen: Kommer strømmen fx fra vindmøller eller kulkraftværker, og foregår transporten vha. diesel- eller benzinbiler? ${ }^{4}$ Det gør en sådan model dårligt egnet til at vurdere effekterne af klimapolitiske tiltag på økonomien og effekten af økonomisk politik på udledninger fra økonomisk aktivitet. Dette problem kan imødegås ved en øget detaljeringsgrad. Hvis den tilstrækkelige information kan fremskaffes (om muligt andetstedsfra end nationalregnskabet), kan de kritiske sektorer opdeles i mere detaljerede delsektorer. Denne tilgang med større deltaljeringsgrad, men samme grundlæggende struktur, er relativt hyppigt anvendt i miljøøkonomiske modeller. Eksempler herpå er den norske SNOW-NO, den svenske EMEC (version 2.0) og den amerikanske EPPA-model.

For at opnå en realistisk beskrivelse af de kritiske sektorer trækker arbejdet med GRØN REFORM derfor også på "tekniske" og specialiserede modeller. Tekniske modeller bygger dog ofte på vidt forskellige antagelser og metoder sammenlignet med gængse økonomiske modeller og er derfor svære at forene. Et primært bidrag i projektet er at integrere tekniske modeller i GRØN REFORMs modelramme. Et eksempel herpå er modelleringen af energisektoren, hvor der er udviklet nye metoder til at forene økonomiske og tekniske modeller (se Berg og Eskildsen 2019).

\footnotetext{
${ }^{3}$ Drivhusgasserne er opgjort som CO2-ækvivalenter. Drivhusgasser fra afbrænding af biomasse samt fra international transport udført af danskejede transportvirksomheder er medtaget, selvom disse to komponenter ikke indgår i Danmarks klimaregnskab over for FN (UNFCCC).

${ }^{4}$ Med den "nuværende sektoropdeling" menes der nationalregnskabets 69-gruppering, der er den mest detaljerede brancheopdeling, den nuværende REFORM model omfatter.
} 


\subsection{El- og varmesektoren}

I modelleringen af el- og varmesektoren tager vi udgangspunkt i tre spørgsmål:

1. Hvordan kan vi modellere sektoren, så vi kan evaluere effekten af klimapolitik på emissioner?

2. Kan vi beskrive hvilke investeringer, der er nødvendige for en ambitiøs grøn omstilling af forsyningssektoren?

3. Hvad er omkostningerne ved specifikke målsætninger for vedvarende energi, både i form af de nødvendige investeringer, og i form af svingende priser og evt. mindsket forsyningssikkerhed?

For at kunne svare realistisk på alle tre grundspørgsmål følger vi to strategier. For det første øger vi detaljeringsgraden i modellen ved at basere modelleringen af energisektoren på tekniske data for teknologiernes omkostningsstruktur. For det andet modellerer vi med inspiration fra energisystemmodeller som Ramses og Balmorel eksplicit, hvordan forskellige teknologier konkurrerer på elmarkedet.

Til beskrivelse af den eksisterende sammensætning af el- og varmesektoren i Danmark anvendes data fra Energiproducenttællingen. Her samles data fra alle el- og fjernvarmeproducenter, der leverer el og/eller varme til et offentligt net. Sammenholdes Energiproducenttællingen med Energistyrelsens teknologikatalog for produktionsteknologier, kan de økonomisk relevante forhold vurderes for hver enkelt energiproducent i landet. Adgangen til data for de økonomiske forhold for de enkelte værker giver mulighed for at modellere el- og fjernevarmesektoren med en såkaldt bottom-up metode: Når den samlede sektors produktion, forbrug, emissioner m.m. opgøres, så gøres det ved at summe over de individuelle værker. Med den høje detaljeringsgrad i bottom-up metoden kan vi beskrive, hvordan forskellige energiformer anvendes i produktionen i dag, hvordan de forventes at udvikle sig i fremtiden, og hvordan de påvirkes af forskellige miljø- og klimapolitiske tiltag.

En øget detaljeringsgrad er ikke tilstrækkelig i sig selv til at beskrive udfordringerne for den grønne omstilling på længere sigt. Årsagerne er, at produktionen af el fra vedvarende energikilder som vind og sol fluktuerer på en ukontrollérbar måde som følge af udsving i vejret, og at efterspørgslen efter el ligeledes fluktuerer på kort sigt. Det er altså ikke i sig selv nok at vide, hvad det koster at producere strøm fra vindmøller og traditionelle regulérbare kraftværker; vi bliver også nødt til at vide, hvad det koster at matche det svingende udbud til en svingende efterspørgsel. Problematikken med fluktuerende udbud og efterspørgsel er velkendt og bl.a. beskrevet i Joskow (2011) og Delarue og Morris (2015): Hvis fluktuerende energikilder (sol/vind) får en stadigt større rolle at spille i den danske energiforsyning, kræver det en kombination af ekstra investeringer i regulérbar back-up kapacitet, energilagringsfaciliteter og udbyggede kabelforbindelser til udlandet samt tiltag, der tilskynder elforbrugerne til at tilpasse deres forbrug til udsving i 
produktionen. Figur 3.1 illustrerer problemets omfang i Danmark for 2017 ved den såkaldte residuale load kurve: Med den nuværende installerede vindkapacitet vil der være timer på året, hvor hele den danske el-efterspørgsel er tilfredsstillet alene af vind. Når vinden derimod ikke blæser, kan der være et udækket behov på omkring 5.000 MWh. Dette er et behov, der ikke kan tilfredsstilles (alene) ved installation af flere vindmøller.

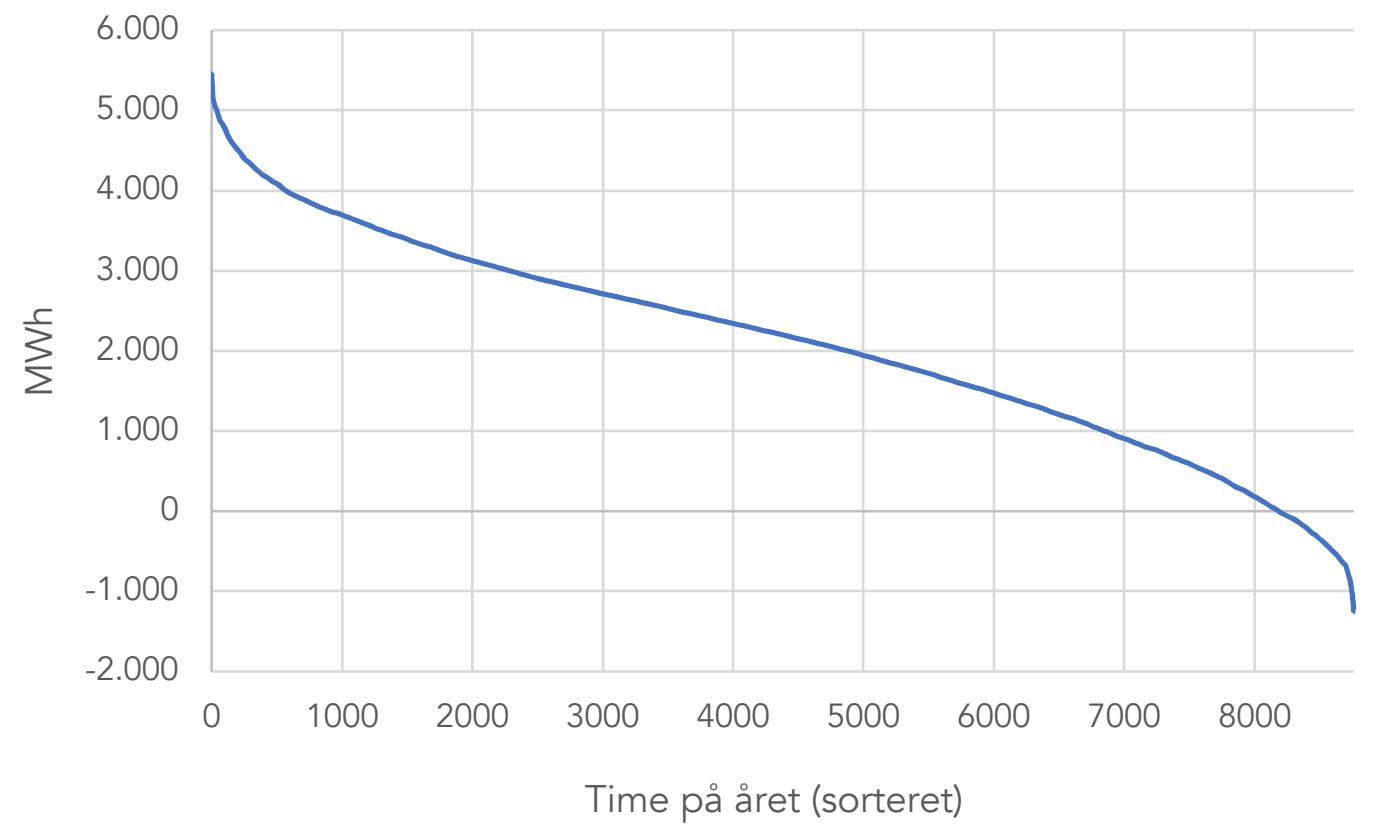

Figur 1: Residual load curve for Danmark 2017. Kurven viser el-efterspørgslen i en time fratrukket produktionen fra fluktuerende energikilder (vind og sol). Kilde: Egne beregninger på baggrund af Energi Data Service, tabel Elbalance.

I GRØN REFORM takler vi udfordringen på to måder. I modsætning til de traditionelle økonomiske modeller, der oftest løser for én ligevægt per år, inddeler GRØN REFORM modellen hvert år i en række kortsigtstilstande, der skal fange vigtigheden af fluktuerende udbud og efterspørgsel. Vi kan således tage højde for flere af de væsentlige faktorer, der bestemmer ligevægtsprisen for el- og varme i hver periode, fx variation i vindhastighed, temperatur og efterspørgsel - samt graden af samvariation herimellem. Derudover modellerer vi eksplicit fire faktorer, der påvirker omkostningerne ved fluktuerende udbud: Back-up kapacitet af regulérbare energikilder, lagerteknologier, muligheder for elhandel over grænserne, samt fleksibel efterspørgsel.

\subsection{Transportsektoren}

Som nævnt i afsnit 3.1. står transporten for en betydelig andel af de eksterne klima- og miljøomkostninger ved den økonomiske aktivitet i Danmark. En særlig udfordring i transportsektoren (herunder privattransport) er at få udskiftet den nuværende køretøjspark til 
at anvende alternative drivmidler som fx el, brint og biogas. Kigger man dog på udviklingen i det dominerende drivmiddels markedsandel i køretøjsparken over de seneste 26 år, så er denne overraskende stabil, jf. ${ }^{5}$ Kun for personbiler har man set en tilbagegang for det dominerende drivmiddel (benzin), men dette har været til fordel for dieselbiler. Trægheden i køretøjsparkens sammensætning er essentiel for en samfundsøkonomisk analyse af transportpolitiske tiltag, og modelleres i GRØN REFORM med udgangspunkt i Gillingham m.fl. (2019) og Abel \& Eberly (1994). Endvidere baseres indtrængningen af nye transportmidler på Energistyrelsens teknologikatalog for alternative drivmidler (Alternativ Drivmiddelmodellen), som beskriver det forventede tekniske potentiale for eksisterende og nye teknologier inden for person-, varebiler, lastbiler, busser, tog, fly og skibe frem mod 2050. Denne tilgang giver grobund for at analysere hvilke politikinstrumenter, der kan sikre udskiftningen af konventionelle drivmidler, så Danmark opfylder sine miljø- og klimapolitiske mål og forpligtigelser.

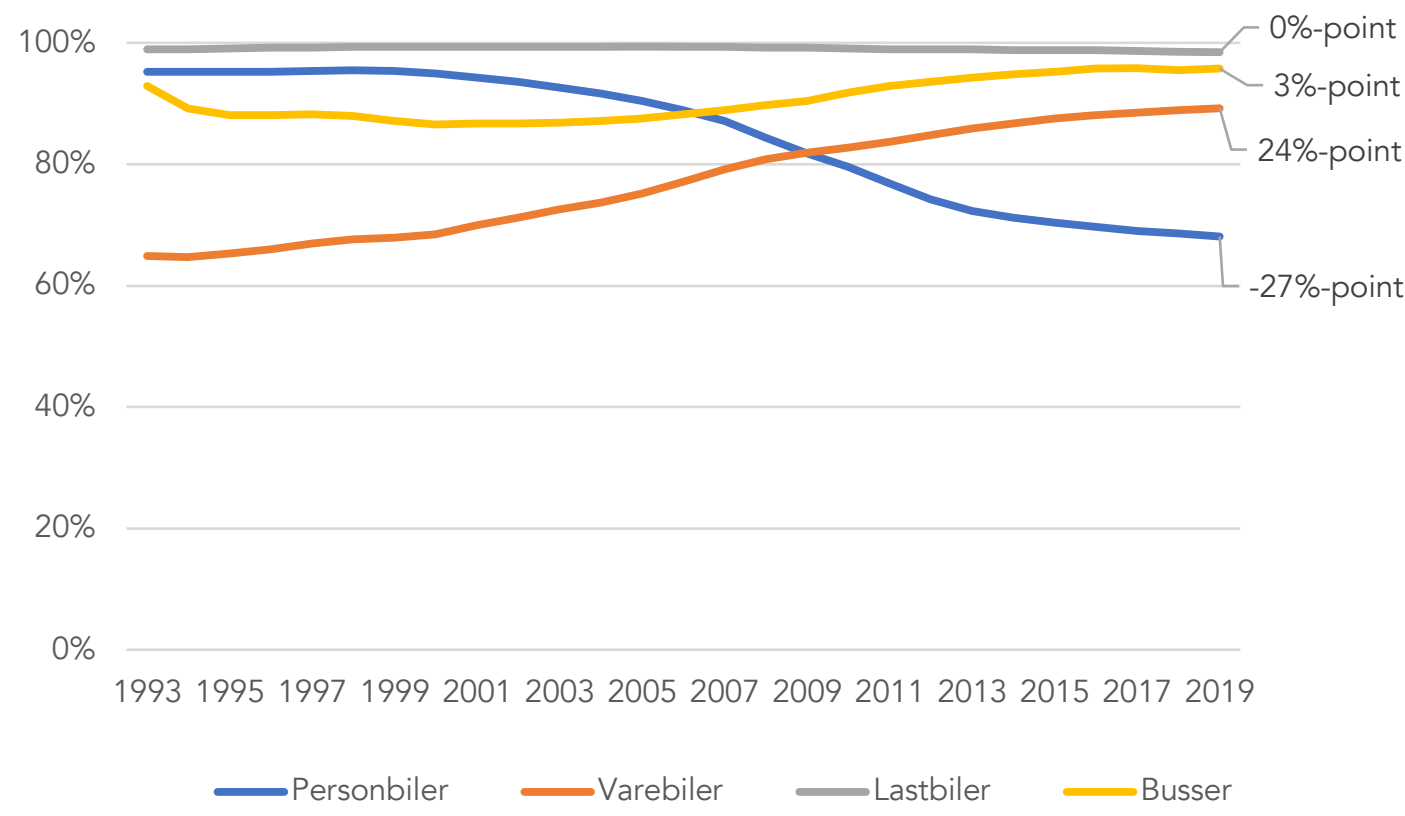

Figur 2: Udviklingen i den dominerende drivmiddels markedsandel for udvalgte transportmidler (benzin for personbiler; diesel for de øvrige transportmidler). Kilde: Egne beregninger på baggrund af Statistikbanken, tabel BIL10, BIL12, BIL15 og BIL18.

Transporten er dog også forbundet med andre eksterne omkostninger i form af bl.a. trængsel og ulykker. Øget trængsel spiller endvidere ind på de privatøkonomiske omkostninger ved transport, da transporttiden forøges. GRØN REFORM inkluderer trængselseffekter ved at basere sig på data fra Landstrafikmodellen, der anvendes til transportøkonomiske

\footnotetext{
${ }^{5}$ For personbiler er benzin det dominerende drivmiddel, mens diesel er det for de øvrige udvalgte transportmidler.
} 
konsekvensberegninger i Danmark. ${ }^{6}$ Dette data muliggør endvidere en opdeling af de forskellige transportydelser (som fx bil, skibsfart, luftfart mm.) på formål som gods- og passagertransport, herunder pendling. Denne opdeling muliggør fx en analyse af en kilometerskats effekt på arbejdsudbuddet, da arbejdsudbuddet er koblet til mængden af pendling. ${ }^{7}$

\subsection{Landbrug}

Landbruget står for ca. en femtedel af udledningerne i Danmarks officielle klimaregnskab over for FN, og udvaskningen af kvælstof og fosfor fra landbrugsjorden er en hovedårsag til Danmarks problemer med at leve op til kravet om et vandmiljø i "god økologisk tilstand" i EU's Vandrammedirektiv. Landbruget bidrager endvidere til luftforurening via fordampning af ammoniak fra landbrugsbedrifterne. Endringer i landbrugets arealanvendelse kan påvirke bindingen og frigivelsen af kulstof, kvælstof og fosfor i jorden, ligesom omlægninger af landbrugsarealer til skovarealer kan bidrage til øget binding af kulstof til gavn for klimaet.

Selvom det primære landbrug kun står for en lille del af den samlede bruttoværditilvækst i dansk økonomi, er sektoren altså meget vigtig fra et miljø- og klimasynspunkt. Dette afspejles i arbejdet med GRØN REFORM modellen, hvor der sondres mellem følgende fire driftsgrene i landbruget: Kvægbrug, svinebrug, planteavl, og fjerkræ m.m. Disse fire driftsgrene opsplittes igen i konventionelle brug og økologiske brug, så der i alt arbejdes med otte delsektorer i landbruget. Nationalregnskabsdata for landbruget splittes op på disse otte sektorer ved hjælp af regnskabsdata for landbruget fra Danmarks Statistik, og landbrugets udledninger modelleres på en måde, der sikrer konsistens med de emissionsregnskaber, der udarbejdes af DCE ved Aarhus Universitet i samarbejde med Danmarks Statistik.

Specifikationen af arealanvendelsen i GRØN REFORM vil endvidere give mulighed for at modellere klimaeffekterne af omlægninger i arealanvendelsen, herunder omlægninger mellem landbrug og skovbrug. I den forbindelse kalibreres emissionskoefficienterne, så de er konsistente med Danmarks officielle klimaregnskab for den såkaldte LULUCF-sektor (LULUCF = Land Use, Land Use Change and Forestry), der udarbejdes af DCE. Derudover giver opsplitningen af landbrugssektoren i GRØN REFORM mulighed for at vurdere miljø- og klimaeffekter af omlægninger mellem konventionelt og økologisk landbrug.

\footnotetext{
${ }^{6} \mathrm{Se} \mathrm{http://www.landstrafikmodellen.dk/.}$

${ }^{7}$ Typisk søger man i samfundsøkonomiske transportanalyser at tage højde for denne afledte arbejdsudbudseffekt på ad hoc manér vha. af en 'skatteforvridningsfaktor' (Transportministeriet 2015). I GRØN REFORM er denne effekt endogen, dvs. bestemt inden for modellens rammer.
} 


\subsection{Affaldsbehandling og genanvendelse}

Affalds- og genanvendelsessektoren er ligeledes en vigtig del af økonomien fra et miljøog klimapolitisk synspunkt, og på EU-niveau såvel som på nationalt plan er der formuleret målsætninger om en betydelig stigning i genanvendelsen af materialer og affald i de kommende år.

På dette område er ambitionen med udviklingen af GRØN REFORM, at modellen skal beskrive affaldssektorens og forbrændingsanlæggenes rolle i energiforsyningen og udledningerne herfra; beskrive omfanget af genanvendelse af materialer i dansk økonomi og genanvendelsens effekter på emissioner af de vigtigste forurenende stoffer; beskrive husholdningernes omkostninger (herunder tidsforbrug) ved håndtering af affald og affaldssortering, og beskrive hvordan ændringer i reguleringen af affaldshåndteringen påvirker graden af genanvendelse og anvendelsen af affald til energiformål.

På dette grundlag vil GRØN REFORM kunne hjælpe til at identificere de faktorer, som bestemmer den samfundsøkonomisk optimale balance mellem genanvendelse af affald og afbrænding af affald til energiformål, når der tages hensyn til de relevante miljøog klimaeffekter.

\subsection{Udledninger fra andre sektorer}

Foruden at modellere emissionerne fra de ovennævnte sektorer skal GRØN REFORM også kunne beskrive udledningen af de forurenende stoffer i Danmarks Statistiks emissionsregnskab fra samtlige øvrige erhverv samt fra husholdningerne og det offentlige.

Ambitionen er at beskrive, hvad der bestemmer virksomhedernes valg af miljøbeskyttelsesindsats inden for rammerne af den gældende miljøregulering. Konkret skal GRØN REFORM kunne give et bud på, hvordan emissionskoefficienterne (udledningerne per produceret enhed) påvirkes af ændrede miljøafgifter og andre former for regulering, der indvirker på virksomhedernes omkostninger ved udledning.

\subsection{Synergieffekter}

Der er potentiale for betydelige synergieffekter mellem projektet om det grønne BNP og GRØN REFORM projektet. Datagrundlaget for kvantificering af miljø- og klimaeffekter vil i stort omfang være det samme i de to projekter, og arbejdet med GNNP-projektet vil føre til estimation af omkostningerne ved forskellige typer af forurening, som kan anvendes til at værdisætte de fysiske miljø- og klimaeffekter af politikændringer, som GRØN REFORM modellen kan beregne.

Der er også potentiale for synergi med Danmarks Statistiks grønne nationalregnskab, der vil levere en del af datagrundlaget for begge projekter. Projekterne kan derved 
illustrere de nyttige anvendelsesmuligheder for det grønne nationalregnskab og inspirere til en videreudvikling og forbedring heraf.

\section{Politologiske aspekter}

De foregående afsnit har beskrevet tilgangen i den økonomiske del af vores samlede forskningsprojekt. I dette afsluttende afsnit redegør vi for nogle foreløbige resultater fra den politologiske del af projektet, som har til formål at afdække, hvilke barrierer der kan være for øget anvendelse af det grønne nationalregnskab og andre "grønne" økonomiske analyseredskaber som de ovenfor beskrevne.

\subsection{Det grønne nationalregnskab}

I februar 2017 udgav Danmarks Statistik for første gang et samlet grønt nationalregnskab (GNR) for Danmark. GNR er et selvstændigt regnskab for miljørelaterede forhold og naturressourcer og opstillet som et såkaldt 'satellit-regnskab' i tilknytning til det konventionelle nationalregnskab, hvorved de samme statistiske afgrænsninger, definitioner og klassifikationer er anvendt. Dermed indgår i GNR en række datasæt, der bl.a. muliggør statistisk mere konsistente analyser af, fx hvordan økonomiske aktiviteter i Danmark afhænger af og påvirker beholdningen af fornybare og ikke fornybare ressourcer (fossile energikilder, mineraler, fisk, skove); hvordan produktion og forbrug hænger sammen med udledning af $\mathrm{CO}_{2} \mathrm{~m} . \mathrm{v}$.

Med andre ord sætter GNR andre vidensproducerende aktører (fx forskningsenheder, ministeriers og partiers analyseenheder, tænketanke m.v.) i stand til at gennemføre statistisk set mere velfunderede analyser af sammenhænge mellem den samlede økonomiske udvikling og udviklingen på miljø- og klimaområdet i Danmark, jf. Gravgaard Pedersen (2013). GNR kan altså potentielt tjene som informationsgrundlag for en mere evidensbaseret politikudvikling, hvor økonomisk politik, miljø- og klimapolitik og forskellige sektorpolitikker kan analyseres og vurderes i sammenhæng.

Et selvstændigt spørgsmål i den sammenhæng er, om etableringen og vedligeholdelsen af et GNR i Danmark alene er tilstrækkelig forudsætning for, at sådanne aktører også gennemfører den type analyser, eller om der også kan forekomme yderligere barrierer for brugen af GNR.

Nærmere bestemt undersøger indeværende politologiske delprojekt "potentialer og langsigtede muligheder for en re-orientering af forskellige dele af den danske centraladministration i retning af anvendelse af det grønne nationalregnskab og grønt BNP som supplement eller alternativ til det konventionelle BNP”. Projektet søger endvidere at identificere "praktiske, institutionelle og diskursive barrierer for en sådan re-orientering."

I det efterfølgende præsenteres for det første et summarisk overblik over nyere international litteratur om nationale vidensregimer samt litteratur om samspillet mellem 
statistik og politik. Dernæst redegøres kort for udvalgte karakteristika ved det danske 'grønne' vidensregime. Endelig præsenteres et kortfattet resumé af resultaterne af en kvalitativ interviewundersøgelse blandt udvalgte aktører i det danske grønne vidensregime angående eventuelle yderligere barrierer for anvendelsen af det nyetablerede GNR.

\subsection{Analytisk ramme: Vidensregimer}

I komparativ politisk økonomi er der gennem de seneste år opstået en støt stigende interesse for hvorvidt, hvordan og på hvilke forskellige måder forskellige typer af politiskøkonomiske ideer, analyser, viden, data og statistik spiller sammen med og evt. strukturerer politiske beslutningsprocesser, jf. fx Béland \& Cox (2010), Blyth (2002), Campbell \& Pedersen (2001), Campbell (2004) og Schmidt (2008). Fx er forskere begyndt at kortlægge såkaldte vidensregimer, der betegner det sæt af "vidensorganisationer som fx tænketanke, statslige forskningsenheder, partiers analyseenheder og andre, der producerer og udbreder policy-ideer. [...] Vidensregimer er altså det organisatoriske og institutionelle maskineri, der genererer data, viden, policy anbefalinger og andre ideer, som påvirker den offentlige debat og policy-making" (Campbell \& Pedersen 2014, 6). Litteraturen viser bl.a., at vidensregimer er organiseret forholdsvist forskelligt i forskellige nationale kontekster.

Ligeledes er der opstået en litteratur, som mere specifikt beskæftiger sig med (det mest hensigtsmæssige) samspil mellem miljø- og klimastatistik (som fx GNR) på den ene side og politisk-økonomiske beslutningsprocesser på den anden, jf. fx Garnåsjordet m.fl. (2012), Boulanger (2007), og Hezri \& Dovers (2006). Det er en diskussion, som også nationale statistikinstitutioner og internationale organisationer bidrager til. Fx har det hollandske miljøvurderingsagentur Netherlands Environmental Assessment Agency udgivet rapporten From Statistics to Policy: The development and application of environmental statistics and environmental accounts in the Netherlands (se Oosterhuis m.fl. 2016). Rapporten identificerer (1) hvem og hvilke typer af brugere af miljø- og klimastatistik, der findes i det hollandske vidensregime; (2) hvordan disse anvender statistikken; og (3) hvorvidt statistikken imødekommer disse gruppers faglige og politiske behov.

Også Verdensbanken har i 2016 etableret Forum on Natural Capital Accounting for Better Policy Decisions, der hvert år samler statistikere, eksperter og politiske beslutningstagere fra hele verden for at diskutere, hvordan miljø- og klimastatistik (herunder særligt grønne nationalregnskaber) kan spille bedre sammen med demokratiske beslutningsprocesser. I sin seneste rapport Taking Stock and Moving Forward (Vardon m.fl. 2017) understreger Verdensbankens forum bl.a. behovet for i diskussionen at skifte fokus fra udbyderne af statistik (dvs. nationale statistikinstitutioner) til efterspørgerne af miljøog klimastatistik (dvs. det bredere vidensregime bestående politiske beslutningstagere, centraladministration, interesseorganisationer, tænketanke, forskere osv.) 
Dog synes disse litteraturer at kunne suppleres yderligere. Dels taler de to litteraturer ikke til hinanden. Dels beskæftiger vidensregime-litteraturen sig ikke med mere domæne- eller policy-specifikke vidensregimer såsom 'grønne' nationale vidensregimer. Og endelig findes der i dansk kontekst, ifølge forfatternes kendskab, ikke for nuværende tilsvarende analyser og diskussion om det bredere samspil mellem miljø- og klimastatistik (som tilvejebragt fx af GNR) og det bredere danske vidensregime.

\subsection{Danmarks "grønne" vidensregime}

Dét man kan betegne som Danmarks grønne vidensregime, er forholdsvist bredt og differentieret og rummer mange forskellige typer af organisationer med forskellige grader af videns- og analysekapacitet.

Dels er der i den danske centraladministration (i både de økonomiske ministerier som fx Finansministeriet, Skatteministeriet m.v.) og de enkelte ressortministerier (fx Miljø- og Fødevareministeriet, Klima-, Energi- og Forsyningsministeriet) en vis vidensog analysekapacitet på det miljø- og klimapolitiske område. Ligeledes eksisterer der særskilt på det miljø- og klimapolitiske område to statsfinansierede, uafhængige råd: Det Miljøøkonomiske Råd og Klimarådet. Hertil kommer også den privat finansierede grønne tænketank CONCITO samt en række danske interesseorganisationer og NGO'er (fx Dansk Industri, Landbrug og Fødevarer, Økologisk Råd, NOAH, Greenpeace, Danmarks Naturfredningsforening m.v.) med en vis "grøn" analysekapacitet. Derudover besidder de politiske partier i nogen grad kapacitet på området.

I regi af vort forskningsprojekt er der gennemført en kvalitativ interviewundersøgelse blandt udvalgte aktører i det grønne vidensregime. Med afsæt i litteraturen om vidensregimer samt forudgående pilotinterviews er 24 potentielle respondenter identificeret. Af disse har 12 medvirket i interviews. Andre har udtalt sig på betingelse af anonymitet, mens nogle ikke ønskede at medvirke. De enkelte interviews er gennemført som semistrukturerede interviews, med afsæt i en fast interviewprotokol med særlig fokus på de barrierer, aktørerne selv oplevede som hindringer for at bringe GNR i relevant anvendelse i den politiske beslutningsproces.

Interviews er gennemført i perioden juni 2017 til marts 2018. Samtlige interviews blev optaget og efterfølgende transskriberet med henblik på videre analyse og fortolkning. De transskriberede interviewdata blev underkastet en semiåben kvalitativ kodning. I det efterfølgende resumeres udvalgte konklusioner fra analysen.

\subsection{Barrierer for anvendelse af det grønne nationalregnskab}

Centrale aktører i det danske 'grønne' vidensregime fremhævede tre overordnede typer af barrier for anvendelse af GNR i en bredere dansk politisk og administrativ kontekst. 
For det første vurderede en række af undersøgelsens respondenter, at GNR langtfra kan stå alene som vidensgrundlag for bredere politiske beslutningsprocesser på det grønne område. De mange data og informationer i GNR må ifølge dem nødvendigvis omsættes til andre typer af miljø- og klimaøkonomiske analyser og viden, fx et grønt BNP, grønne økonomiske regnemodeller og/eller grønne værdisætningsstudier m.v., førend de kan indgå i den politiske beslutningsproces. Et analysearbejde som i sig selv er omkostningstungt og ressourcekrævende, og som ofte ikke er mulig at gennemføre grundet netop mangel på ressourcer.

For det andet anfører nogle respondenter, at der selv i de tilfælde, hvor data fra GNR omsættes til andre typer af økonomiske analyser (fx cost-benefit-analyser, cost-effectiveness-analyser, beregner af grønt BNP m.v.) kan forekomme yderligere politiske og/eller administrative barrierer for, at sådanne analyser også efterfølgende inddrages i den politiske beslutningsproces. Fx argumenterer nogle respondenter for, at idealet om arbejdsdeling mellem folkevalgte politiske beslutningstagere og embedsværk/administration i praksis ikke altid overholdes. ${ }^{8}$ GNR bliver derfor ifølge nogle respondenter simpelthen ikke anvendt, fordi de analyser og politiske beslutningsgrundlag, som det kan danne datagrundlag for, blokeres og/eller underkendes som irrelevante eller modvirkes undervejs af forskellige administrative led i den politiske beslutningsproces.

For det tredje vurderer nogle respondenter, at det "grønne vidensregime" i Danmark ikke er lige så fagligt solidt og veludbygget som i sammenlignelige lande (fx Holland). Samlet set vurderer flere respondenter, at der i Danmark er få og forholdsvist ressourcesvage analyseproducerende organisationer eksternt til centraladministrationen, der besidder tilstrækkelig analysekapacitet til at producere de nødvendige typer af miljø- og klimapolitiske analyser, beslutningsgrundlag m.v. Det betyder ifølge disse respondenter, at der udarbejdes et mere begrænset og mindre pluralistisk udbud af økonomiske analyser, som alt andet lige reducerer efterspørgslen på GNR's data - og som således udgør en indirekte barriere.

\section{Konklusion}

Artiklen har argumenteret for, at der er væsentlige sammenhænge mellem den økonomiske udvikling og tilstanden af miljøet og klimaet. For at leve op til klimapolitiske mål som Paris-aftalen og miljøøkonomiske mål som fx vandrammedirektivet udgør, er der behov for en systematisk samtænkning af økonomi og miljø. Artiklen beskrev to redskaber, der kan realisere en sådan systematisk samtænkning: Et grønt BNP og en grøn simulationsmodel, GRØN REFORM.

\footnotetext{
${ }^{8}$ Den ideale arbejdsdeling værende politiske beslutningstagere, der formulerer overordnede politiske målsætninger, mens embedsværket varetager det faglige arbejde med at analysere, hvordan og med hvilke typer politiske instrumenter, initiativer og tiltag, sådanne målsætninger billigt muligt kan indfris.
} 
Det grønne BNP udvider det traditionelle begreb for den samlede økonomiske aktivitet (BNP) ved at indregne værdien af ikke-markedsomsatte miljøgoder og nettotilvæksten i såkaldt naturkapital. Det grønne BNP kan dermed populært sagt vurdere, hvorvidt den økonomiske aktivitet er sket på bekostning af miljøet. Vi bemærkede derefter, at det grønne BNP er en statistisk indikator, der baseres på historisk data. Den grønne simulationsmodel GRØN REFORM udvikles derimod med henblik på at vurdere kontrafaktiske scenarier. Ved at indarbejde miljø- og klimahensyn i en generel ligevægtsmodel for den danske økonomi, kan politiske tiltag konsistent vurderes både i forhold til økonomiske og miljø- og klimamæssige effekter.

Slutteligt argumenterede vi for, at udviklingen af analytiske redskaber ikke nødvendigvis er nok i sig selv; der kan være barrierer i den politiske proces, der problematiserer skridtet fra udvikling til anvendelse af 'grønne' analyseredskaber. På den ene side synes der at være en vis efterspørgsel efter nye analyseværktøjer som fx det grønne BNP og en miljø- og klimaøkonomisk model for dansk økonomi, som kan bidrage til at operationalisere og nyttiggøre den viden og de data, der er indeholdt i det grønne nationalregnskab. På den anden side antyder svarene fra nogle af respondenterne, at sådanne ny analyseredskaber i miljø- og klimapolitikken ikke nødvendigvis automatisk vil blive inddraget $\mathrm{i}$ policy-processerne, når de er færdigudviklede, da de ikke nødvendigvis fremmer interesserne hos alle centrale spillere i den politiske proces.

\section{Litteratur}

Agimass, F., Lundhede, T., Panduro, T., Jacobsen, J.B. (2018). The choice of forest site for recreation: A revealed preference analysis using spatial data. Ecosystem Services, årg. 31, part C, s. 445-454. https://doi.org/10.1016/j.ecoser.2017.11.016

Bakhtiari, F., Jacobsen, J.B., Thorsen, B.J., Lundhede, T.H., Strange, N., Boman, M., (2018). Disentangling distance and country effects on the value of conservation across national borders. Ecological Economics, årg. 147, s. 11-20. https://doi.org/10.1016/j.ecolecon.2017.12.019

Bateman, I., Harwood, A, Mace, G.M., Watson, R.T., Abson, D.J., Andrews, B., Binner, A., Crowe, A., Day, B.H., Dugdale, S., Fezzi, C., Foden, J., Hadley, D., HainesYoung, R., Hulme, M., Kontoleon, A., Lovett, A. A.; Munday, P., Pascual, U., Paterson, J., Perino, G., Sen, A., Siriwardena, G., van Soest, D., Termansen, M. (2013). Bringing Ecosystem Services into Economic Decision-Making: Land Use in the United Kingdom. Science, årg. 341(6141), s. 45-50. https://doi.org/10.1126/science.1234379

Béland, D., \& Cox, R. H. (2010). Ideas and politics in social science research. Oxford: Oxford University Press. https://doi.org/10.1093/acprof:oso/9780199736430.001.0001 
Berg, R. \& Eskildsen J. (2019). Modelling the energy sector in a computable general equilibrium framework: A new approach to integrated bottom-up and top-down modelling.

Blyth, M. (2002). Great transformations: Economic ideas and institutional change in the twentieth century. Cambridge: Cambridge University Press. https://doi.org/10.1017/CBO9781139087230

Boulanger, P.M. (2007). Political uses of social indicators: overview and application to sustainable development indicators. International Journal of Sustainable Development, årg. 10(1-2), s. 14-32. https://doi.org/10.1504/IJSD.2007.014411

Bue-Bjørner, T., Termansen, M. (2014). Brugsværdier af naturområder i Danmark. Nationaløkonomisk Tidsskrift, årg. 152, s. 1-23.

Campbell, J.L. \& Pedersen, O.K. (2001). The rise of neoliberalism and institutional analysis. Princeton: Princeton University Press. https://doi.org/10.1017/S1537592703670155

Campbell, J.L. (2004). Institutional change and globalization. Princeton: Princeton University Press.

Campbell, J.L., \& Pedersen, O.K. (2014). The national origins of policy ideas: Knowledge regimes in the United States, France, Germany, and Denmark. Princeton: Princeton University Press.

Campbell, D., Vedel, S.E., Thorsen, B.J., Jacobsen, J.B. (2014). Heterogeneity in the WTP for recreational access - distributional aspects. Journal of Environmental Planning and Management, årg. 57(8), s. 1200-1219. https://doi.org/10.1080/09640568.2013.793173

Crutzen, P.J. (2002). Geology of mankind. Nature, årg. 415(23), s. 23-23. https://doi.org/10.1038/415023a

Daly, Herman E. and Joshua Farley (2011). Ecological Economics, Second Edition. Island Press.

Dasgupta, P. \& Mäler, K.-G. (2000). Net National Product, wealth, and social well-being. Environment and Development Economics, årg. 5(1), s. 69-93. https://doi.org/10.1017/S1355770X00000061

De Økonomiske Råd (2017). Økonomi og Miljø 2017. Rapport til Det Miljøøkonomiske Råd.

Delarue, E, \& J. Morris (2015). Renewables Intermittency: Operational Limits and Implications for Long-Term Energy System Models. MIT Joint Program on the Science and Policy of Global Change, Report No. 277, March 2015.

Dubgaard, A. og Ladenburg, J. (2007). Værdisætning af miljøgoder. I: Kirsten Halsnæs, Peder Andersen og Anders Larsen, red., Miljøvurdering på økonomisk vis. Juristog Økonomforbundets Forlag.

Garnåsjordet, P. A., Aslaksen, I., Giampietro, M., Funtowicz, S., \& Ericson, T. (2012). Sustainable development indicators: from statistics to policy. Environmental Policy and Governance, årg. 22(5), s. 322-336. https://doi.org/10.1002/eet.1597 
Gillingham, K. \& J.H. Stock (2018). The cost of reducing greenhouse gas emissions. Journal of Economic Perspectives, årg. 32, s. 53-72. https://doi.org/10.1016/j.enpol.2011.02.042

Gravgaard Pedersen, O. (2013). Grønne nationalregnskaber og det grønne BNP: metoder og muligheder. Danmarks Statistik.

Hamilton, K. (1994). Green adjustments to GDP. Resources Policy, årg. 20, s. 155-168. https://doi.org/10.1016/0301-4207(94)90048-5

Hartwick, J. (1990). Natural resources, national accounting and economic depreciation. Journal of Public Economics, årg. 43(3), s. 291-304. https://doi.org/10.1016/0047-2727(90)90002-Y

Hartwick, J. (1994). National wealth and Net National Product. Scandinavian Journal of Economics, årg. 96(2), s. 253-256. https://doi.org/10.2307/3440602

Hezri, A. A., \& Dovers, S. R. (2006). Sustainability indicators, policy and governance: Issues for ecological economics. Ecological Economics, årg. 60(1), s. 86-99. https://doi.org/10.1016/j.ecolecon.2005.11.019

Jacobsen, J.B., Boiesen, J.H., Thorsen B.J., Strange, N. (2008). What's in a name? The use of quantitative measures versus 'Iconised' species when valuing biodiversity. Environmental and Resource Economics, årg. 39(3), s. 247-263. https://doi.org/10.1007/s10640-007-9107-6

Joskow, P.L. (2011). Comparing the Costs of Intermittent and Dispatchable Electricity Generating Technologies. American Economic Review, årg. 101(3), s. 238-241. https://doi.org/10.1257/aer.101.3.238

Klimarådet (2018). Status for Danmarks klimamålscetninger og-forpligtelser 2018. København, november 2018.

Levitt, C.J., M.S. Pedersen \& A. Sørensen. (2015). Examining the efforts of a small, open economy to reduce carbon emissions: The case of Denmark. Ecological Economics, årg. 119, s. 94-106. https://doi.org/10.1016/j.ecolecon.2015.08.002

Mäler, K.-G. (1991). National accounts and environmental resources. Environmental and Resource Economics, årg. 1, s. 1-15.

Mota, R.P., Domingos, T., Martins, V. (2010). Analysis of genuine saving and potential green net national income: Portugal, 1990-2005. Ecological Economics, årg. 69(10), 1934-1942. https://doi.org/10.1016/j.ecolecon.2010.04.026

Neumayer, E. (2013). Weak versus Strong Sustainability - Exploring the Limits of Two Opposing Paradigms. Fourth Edition. Edward Elgar, Cheltenham, UK and Northhampton, MA, USA. https://doi.org/10.4337/9781781007082

Oosterhuis, F. et al. (2016). From Statistics to Policy: The Development and application of environmental statistics and environmental accounts in the Netherlands, Policy Study (PBL publication number 2433 ed.). The Hague: PBL Netherlands Environmental Assessment Agency.

Panduro, T.E., Jensen, C.U., Lundhede, T.H., von Graevenitz, K., Thorsen, B.J. (2018). Eliciting preferences for urban parks. Regional Science and Urban Economics, årg. 73, s. 127-142. https://doi.org/10.1016/j.regsciurbeco.2018.09.001 
Pezzey, J.C.V., Hanley, N., Turner, K., Tinch, D. (2006). Comparing augmented sustainability measures for Scotland: Is there a mismatch? Ecological Economics, årg. 57(1), s. 60-74. https://doi.org/10.1016/j.ecolecon.2005.03.006

Ruddiman, W.F. (2013). The Anthropocene. Annual Review of Earth and Planetary Sciences, årg. 41, s. 45-68. https://doi.org/10.1146/annurev-earth-050212-123944

Schandl, H. et al. (2017). Global material flows and productivity - Forty years of evidence. Journal of Industrial Ecology, årg. 22(4), s. 827-838. https://doi.org/10.1111/jiec. 12626

Schmidt, V. A. (2008). Discursive institutionalism: The explanatory power of ideas and discourse. Annual Review of Political Science, årg. 11, s. 303-326. https://doi.org/10.1146/annurev.polisci.11.060606.135342

Steffen, W. et al. (2018). Trajectories of the Earth System in the Anthropocene. Proceedings of the National Academy of Sciences, årg. 115(33), s. 8252-8259. https://doi.org/10.1073/pnas.1810141115

Stern, D.I. (1997). Limits to substitution and irreversibility in production and consumption: A neoclassical interpretation of ecological economics. Ecological Economics, årg. 21, s. 197-215. https://doi.org/10.1016/S0921-8009(96)00103-6

Sørensen, P.B. (2019a). Environmental, energy, and climate policy. I: P.M. Christiansen, J. Elklit \& P. Nedergaard, red., Oxford Handbook of Danish Politics, forthcoming on Oxford University Press.

Sørensen, Peter Birch (2019b). A theoretical framework for estimating the Green Net National Product in a small open economy. Working Paper. Department of Economics, University of Copenhagen.

TEEB (2010). The Economics of Ecosystems and Biodiversity: ecological and economic foundation. Edited by P. Kumar. London og Washington: Earthscan.

Transportministeriet (2015). Manual for samfundsøkonomisk analyse på transportområdet-Anvendt metode og praksis i Transportministeriet. Marts 2015. 